\title{
Restructuring the Public Sphere for Social Order in the Niger Delta through Polycentric Planning: What Lessons for Africa?
}

\author{
Dr. Samson Ranti Akinola \\ Development Planner \& Environmentalist, \\ Department of Architecture, Covenant University \\ 10 Idiroko Road, Canaan Land, Ota, Ogun State, Nigeria \\ Email:srakinola@yahoo.com
}

\begin{abstract}
The increasing deprivation, neglect and orchestrated politics of exclusion by the Nigerian-state against the people of the Niger Delta can be traced to the structurally-defective and centralized governance arrangements in the Niger Delta. The consequent stiff resistance, violent reactions, militancy and hostage taking triggered by this politics of exclusion in the region have confirmed that people matter in politics. This paper argues that in some ways, the weakness of centralized and structurally-defective governance in the Niger Delta provides an opportunity for community self-governing institutions to play the role that governments and their agencies have abandoned. Using the Institutional Analysis and Development (IAD) framework, this paper engages in problem solving and solution seeking strategies that could help restructure the public sphere in the Niger Delta. This paper demonstrates principles and practices needed to make polycentric planning, self-governance and adaptive development strategies resolve socio-economic and political crisis. It is in light of this exigency that this paper develops an African Public Sphere Restructuring Model (APSRM) that derives inspirations and workability mechanisms from twelve (12) African development models that cut across several sectors of the economy in the Niger Delta.
\end{abstract}

\section{Keywords}

Restructuring; Public Sphere; Social Order; Niger Delta; Polycentric Planning; Africa

\section{Introduction}

The present structure of governance in the Niger Delta is highly centralized. This centralized system, which excludes the people from decision making and the benefits of oil, is one of the major factors that has accounted for the protracted crisis in the region. As the seventh largest producer of oil and gas in the world and the largest in Africa, the Niger Delta contributes over $40 \%$ to the Nigeria's GDP, about $90 \%$ of total annual earnings and about $80 \%$ of the 
national gross income (Federal Government of Nigeria [FGN] 2008, 212). Despite the population of the region (about 33.5 million) accounting for about $23.0 \%$ of the national population (FGN 2008, 189), the Niger Delta communities where the crude oil is extracted generally suffer poverty, neglect, environmental degradation, denial of fundamental human rights and transport bottlenecks (Naanen 1995; Obi 2004, 450; Akinola 2008b, 89). About $95 \%$ of the people live in small rural settlements with less than 5,000 in population and $85 \%$ of this people depends on informal enterprises (fishing, canoe carving, subsistent agriculture, blacksmithing, etc) as their primary sources of livelihood (Okaba 2008, 29).

In spite of its strategic economic importance, the demographic picture of the region as shown by the Human Development Index ${ }^{1}$ (HDI) is deplorable. The HDI of the region is as low as 0.564 , compared with other regions and nations with the same oil and gas resources such as Saudi Arabia (0.800), United Arab Emirate (0.846), Kuwait (0.844), Libya (0.799), etc. (Human Development Index Report 2005:6 cited in Okaba 2008, 30). Average life expectancy in the Niger Delta is 46.8 years. There is also a high mortality of young children - of every 1000 new born, 200 die by the age of 5. This is one of the poorest amongst developing countries (FGN 2008, 221), especially when compared with the national infant mortality rate of Nigeria, which is 14 per 1000 live at births (Okaba 2005a, 55). Access to health was estimated to be available to only $56.5 \%$ of the population and population per one hospital bed was as high as 1,277 people (Okaba 2005a, 55). According to Michael Watts $(2008,47)$, there is one doctor for every 150,000 inhabitants of the oil rich states of Bayelsa and Delta. Similarly, educational attainment at primary and secondary levels suffers from a high teacher-pupil ratio - 1:42, compared with the national average of 1:36 (FGN 2008, 221). This, invariably, resulted in large number of drop-outs. At the same time, unemployment is about $30 \%$ of the available labour force in the region (FGN 2008, 212).

These sordid and deplorable conditions of living in the region are consequential upon the public sphere being dominated by the few elite with "particularistic" concerns at the exclusion of the people. The affluence exhibited by many workers of the oil companies and political office holders in Nigeria sharply contrasts with the social deprivation of most residents of oil communities whose livelihoods are threatened (Akinola 1992, 1998, 2000, 2003a,

${ }^{1}$ Human Development Index is a standard measure of well being of people, encompassing the longevity of age, knowledge and decent standard of living in terms of access to safe and clean water, quality health and education services, electricity, road, gainful employment, political participation, rule of law, etc. It is measured with 1 being the highest ranking score. 
2005d, 2008b, 89; Obi 2004, 448). The orchestrated politics of exclusion in the region breeds resentment and aggression. In response, the people of oil communities resisted this oppression of the federal government in various ways (Douglas and Ola 1999, 334; Obi 2000a, 281). Consequently, four major groups, as identified by Akinola (2008b, 90), with diverse interests have emerged strategizing for different reasons. As a result, the challenges in the region have become complex and complicated.

The problem is largely a case of institutional dilemma which confirms the problem of "disconnect" that is caused by the absence of appropriate institutional mechanisms that could motivate the people (elite and non-elite) to work together as partners in development in the region. The stakeholders in development - governments, oil companies, other agencies and the Niger Delta people - operate on parallel lines, instead of as colleagues with equal standing within governance and development arenas. Without the citizens playing an active role in decision making, governance process would continue to exclude and marginalize them.

This paper identifies the missing links as well as the areas of neglect by scholars and policymakers in the governance of public sphere and community affairs in the Niger Delta. It uses the Institutional Analysis and Development (IAD) framework to discuss repetitive missing links between and among the stakeholders in the governance of the public sphere and to proffer possible solution to the challenges in the region. According to some Tocquevillian analytics, the public sphere as one of the four terrains of the public landscape is the central axis of public life where deliberation according to "universal rules" exposes citizens to competing viewpoints through public debates, teaches them to become critical, tolerant and enabling them to transform their "particularistic" concerns into "universal" ones. It also provides women, as well as racial, ethnic, and other marginalized groups, a way to broaden the public agenda and therefore a way to gain access and entry into public life (Mansbridge 1983; Habermas 1989; Colas 1997; Alger 1998; Forment 2003, 16-17).

This paper represents a step a-head of previous works done by the author in an attempt to find a possible solution to the challenges confronting the Niger Delta. It builds upon the foundation laid in a paper titled, "Coping with Social Deprivation through Self-Governing Institutions in Oil Communities of Nigeria”, published in Africa Today, (Fall 2008), Volume 55, Number 1, pages 89-107.

Akinola (2008b) found that the inability of the elites leadership, governments and oil companies in the Niger Delta to respond appropriately to the needs and aspirations of the citizenry provoked opportunity for the people to carry out social responsibility that the state has effectively dodged over the 
years. The local people through self-governing institutions in the region have been able to respond to social challenges by exploring pre-colonial governance heritage and to certain extents have been able to address their daily needs (Akinola 2008b). The contention of this paper is that these people-centred creativities and adaptation strategies should form the basis for reconstructing the public sphere in the Niger Delta. It is in this regard that polycentric planning and decision making arrangements that regard community self-governing institution as a major player in crisis resolution and development become imperative. Polycentric planning is a deliberate act of setting up multilayered and multicentred institutional mechanism that regards self-governing capabilities of local communities as foundation for reconstituting order from the bottom up. It can also be described as the process of ordering the use of physical, human and institutional resources as well as engaging the citizens in contractual relations with the public authority.

The point of departure of this paper is in problem solving and solution seeking. The paper is, therefore, concerned with how to restructure the public sphere through appropriate institutional mechanism that could bring the Niger Delta people into the main stream of socio-economic and political decisions, thereby synergizing the efforts of the state, oil companies and community institutions through bottom-up and integrative planning. It also suggests an adaptive planning strategy, using multi-layers and multi-centres' institutional arrangements, to connect the stakeholders in a polycentric manner in order to resolve the hydra-headed challenges in the region. In the light of this exigency, this paper develops an African Public Sphere Restructuring Model (APSRM) that derives inspirations and workability mechanisms from twelve (12) African development models that are problem-solving and solution-seeking in several sectors of the economy in the Niger Delta.

\section{The Problematics of Governing the Public Sphere in the Niger Delta}

The challenges in the Niger Delta arising from structurally-defective pattern of governance are summarized as: (a) A large sum of money flowing to the Niger Delta region regularly but with little or no impact on the lives of the people; (b) Party patronage, clientelism, godfatherism and winner-take-all predominating the political system in the region; (c) The failure of local governments in the region to meet the aspirations of the citizenry make the political system irrelevant to the grassroots; (d) The 'disconnect' and alienation result into a widespread gulf between the leaders and the rest of the society, thus culminated into crisis and high level of insecurity; (e) The local people through self-organizing arrangements, shared strategies and problem-solving 
interdependencies are more effective in responding to community needs and aspirations than governments and their agencies.

The general clamour for the Niger Delta is for government to increase the percentage from federation account accruable to the region. The question is: What has happened to the $13 \%$ derivation already being released to the region since 1999 when the percentage deduction from the federation account to the development of the region was increased from 3\%? The gross financial misappropriation of money meant for redressing the problems created by oil exploration has not helped the matter (see Akinola 2008b, 93). The critical question is this: Is the structure that plunders most of the $13 \%$ capable of spreading the effect of $\underline{a}$ higher percentage to the people in the region? The socio-economic and political events in the region within the last fifteen years confirmed that the governance structure in the Niger Delta is grossly incapable of actualising the dreams and aspirations of the citizenry. In order to adequately analyse the challenges in the Niger Delta, Tocquevillian analytics is employed.

\section{Tocquevillians and Public Life in the Niger Delta}

A Frenchman, Alex de Tocqueville's (1966) constructive response to the question where do people turn following the failure of State institutions is contained in his Democracy in America. Instead of turning to the State as the fundamental basis for the constitution of order in human societies, Alex de Tocqueville turned to what he referred to as the village or the township as the basic foundation of society. The foundation upon which American democracy rests is the people at the local level, and the picture is captured in the words of Alexis de Tocqueville:

The township is the only association so well rooted in nature that whenever men assemble it forms itself... the community is the basic unit of collective organization... the people through experience of living together through successive generations work out arrangements among themselves for meeting the requirement of life (Tocqueville, 1966).

He further declares: "In democratic countries the science of association is the mother of science; the progress of all the rest depends upon the progress it has made" (Tocqueville, 1966). Further, he found this type of association to be universal among mankind. They exist among all nations.

Alex de Tocqueville (1966) argues that if societies were to govern themselves for themselves, they would have to develop the art and science of association the fundamental issues of political design. It is important, however, to note that some African scholars have effectively employed Tocquevillian analytics 
in their works (Ayittez 1991, 2006; Olowu 1999, 2006; Ayo 2002; Akinola 2005d, 2007a,f, 2008b). These Tocquevillians in Africa, through their works, confirmed that many peoples of Africa have exercised considerable entrepreneurial capabilities both in creating private enterprises and public facilities and in governing their own relationships with one another.

Based on Tocquevillian analytics, Forment $(2003,18)$ divides the public landscape into four terrains: civil society; economic society; political society and public sphere. Tocquevillians are currently debating the relative importance of each of the four public terrains in the development of democratic life (Walzer 1995; Forment 2003, 15). Four views predominate. Scholars in the first group grant primacy to civil society (Putnam 1993; Bibic and Graziano1994; Wuthnow 1998). According to them, membership in religious, work-based, neighborhood, educational, ethnic-racial, recreational, and other types of associations provide citizens a stable place in which to forge ties of solidarity and to recognize each other as members of the same community. These views are confirmed by recent findings in the Niger Delta (see Akinola 2003a, 2005d, 2008b). However, the works of Tocquevillians in the West show that civil society is fast unraveling as a result of efforts by state officials and economic managers to "colonize" it. Thus civil society's demise has undermined the moral and social foundations of democratic life (Forment 2003:16). The reverse, however, is the case in the Niger Delta where some civil society organizations have assumed the status of self-governing institutions. These institutions were crafted by the people, without external interference, in an attempt to solve their common problems within their community (Akinola 2008b, 103).

Scholars in the second group ascribe similar importance to political society (Huntington 1968; Janowitz 1983; Harbeson, Rothchild and Chazan 1994; Schudson 1998; Diamond 1999). According to their findings in the West, participating in elections, political parties, interest groups, and mass movements provide citizens an opportunity to influence government officials and to use the institutional resources they have to improve their life chances, enabling them to redistribute socioeconomic and cultural power from the privileged "few" to the "many." However, the wealthy and powerful have been far more successful in gaining control of the political arena, while the electorate at large increasingly becomes apathetic and, thus many citizens abandon political society (see Forment 2003, 16).

The same pattern exists in the Niger Delta and this position is confirmed by recent experience. Because of the divorced nature of the people from the governance process, politics in the region is winner-take-all and do-or-die affair. Politics of warfare, invariably, scare most citizens away from the political space. 
There is also the problem of politicization of criminality in the Niger Delta. There are several cases where politicians employed and armed gangs, thugs and hooligans to intimidate opponents or rig elections and later to abandon them after winning elections, while the ammunitions used are not withdrawn from these miscreants. Without jobs and any means of surviving, these thugs later transformed themselves to either militants fighting for emancipation of Deltans or untouchable criminal gangs who harass their fellow citizens on regular basis. Many of these groups have ventured into oil theft, vandalization, kidnappings and violent crime. The strong connections they have with politicians give these gangs greater leverage. This makes insecurity in the region not a simple conflict between the government/oil companies and insurgents as the line between militancy and criminality is now blurred.

The third group of neo-Tocquevillians claims that economic society is the foundation of democracy (Novak 1982; Berger 1986; Hann 1990; Hirst 1994; Kuttner 1997; Mitchell 1997). Market capitalism, they argue, contributes to decentralizing wealth, thereby providing citizens the power they need to defend themselves against state officials and to preserve liberty in the modern world. But according to critics, the proliferation of large corporations and multinational firms throughout economic society has led to a centralization and monopolization of wealth and other types of material and symbolic resources, making it impossible for citizens to practice democracy in economic society or any other public terrain (see Forment 2003, 17).

The fourth group of scholars argues that the public sphere is the central axis of public life (Mansbridge 1983; Habermas 1989; Colas 1997; Alger 1998; Lomnitz 2001). Deliberating in public according to "universal rules" exposes citizens to competing viewpoints and in doing so, teaches them to become critical and tolerant. Public debates enable citizens to transform their "particularistic" concerns into "universal" ones. In addition, the public sphere, more than any of the other domains, provides women, as well as racial, ethnic, and other marginalized groups, a way of broadening the public agenda and therefore a way of gaining access and entry into public life. These changes in the West have democratized the public sphere, but they have also contributed to the decline of critical deliberation and to the spread of "mass entertainment." On their account, democracy has been turned into a "spectator sport" to be viewed in the privacy of one's home (see Forment 2003, 17).

This position is reinforced by experiences in the Niger Delta. For example, the structure for public debates among public officials and citizens in the oil region are non-existent. On this, Obi $(2004,441)$ notes the growing demand for reconstruction of social relations in the Niger Delta, and even in the entire federation of Nigeria. Since the political and economic societies have been 
captured by the elite, they and their surrogates as well as their cronies are the ones that dominate kangaroo and authoritarian "public debates." Whereas citizens in the Niger Delta under the aegis of self-governing institutions constitute the fulcrum of socio economic activities and local development, these citizens at community level are excluded from the political realm and rules making by the elites who make and impose rules on citizens to feather their parochial and selfish interests.

Analysis so far confirmed that the economic society, political society and the public sphere in the Niger Delta are dominated by the elites leaving the self-governing institutions as the only institutions that are people-concerned. This situation in the Niger Delta is highly problematic as there are four major groups operating on parallel lines. The first two groups belong to the elites, while the other two are the non-elites. The elite indigenes that have captured economic society, political society and the public sphere are politicians and bureaucrats. Some of these elites are allegedly involved in oil bunkering. The other group of the elites, though very few are the likes of Ken Saro Wiwa who are passionate about the conditions of ordinary people in the region. Similarly, the non-elites "organize" themselves into two camps. The first group of nonelites adopts crude approach by using violence in making pressure to bear on the Federal Government and oil multinationals. In the second group of non-elites are the grassroots people who invest their sovereignty horizontally in one another through collective action and self-organizing arrangements to address infrastructural problems at the community level (see for details, Akinola 2008b, 90).

In the opening paragraph of The Federalist Papers, Hamilton ([1788] 1961, 33) posed the fundamental puzzle in human societies, "whether societies of men are really capable or not of establishing good government from reflection and choice, or whether they are forever destined to depend for their political constitutions on accident and force." If we understand society as a system of human cooperation, this Hamiltonian puzzle can be formulated as a question: Are human beings capable of cooperating with one another to organize a free, peaceful, and prosperous society? In relation to the Niger Delta, this puzzle can be formulated as five questions: Are the people of Niger Delta capable of cooperating with one another to organize people-oriented public sphere that will produce accountable leaders and basic goods and services of their choice? Are there some roles citizens should play in the process of reconstructing the public sphere and participating in public debates? What are these roles? How can the public space be planned and reconstructed to allow citizens at community level to be involved in decision making, rule-monitoring and enforcement of sanction on rule infraction? What role should citizens at community 
level play in electoral rules making, for example? The argument is that until the public sphere in the Niger Delta is reconstructed, governmental systems as well as goods and services will not be people-focused and democratic; tyranny of the majority will continue to predominate; and peoples of the Niger Delta, regardless of their endowment and entrepreneurial capability, will continue to suffer, while violence, insecurity and poverty will be heightened.

The argument in this section is that the structurally-defective pattern of governance in the Niger Delta makes it difficult for the region to be governed even if the governors are sincere and adept in the act of governance. The way out of this crisis is to fashion out an alternative governance structure that could enable the people to engage themselves in community assembly. At this point, it is important to go into the theoretical framework on which this argument is anchored.

\section{Theoretical Underpinning}

In order to contextualize the line of analysis in this paper, Public Choice Theory (PCT) is adopted. The PCT recognizes the fundamental defects in the centralist model of governance and the persistent failure of the state to meet the collective yearnings and aspirations of the citizenry. This view focuses on the polycentric approach to the constitution of order in a human society where people share a community of understanding in proffering solutions to their own problems of daily life in a rule-ordered relationship (V. Ostrom et al. 1988, 51). The Public Choice scholars emphasize the development of an alternative institutional paradigm by calling attention to the self-governing and self organizing capabilities of the people. Though this alternative paradigm was originally conceived within the context of American experience, it has become a potent alternative effectively employed by African scholars in their works (Ayittez 1991, 2006; Olowu 1999, 2006; Ayo 2002; Akinola 2005d, 2007f, 2008b). These scholars have confirmed the resilience and effectiveness of institutions designed through shared norms and managed by the people through collective action. This is the fundamental of the Institutional Analysis and Development (IAD) framework, developed over the years by Vincent Ostrom and Elinor Ostrom and colleagues at the Workshop in Political Theory and Policy Analysis, Indiana University, Bloomington, USA. The IAD believes in institutional arrangement designed by people who cooperate based on rules and constitution of their choice, and thereby able to resolve socioeconomic and political problems which other people (external to their conditions) are not capable of doing for them. 
Broadly defined, institutions are the prescriptions (rules) that humans use to organize all forms of repetitive and structured interactions including those within families, neighborhoods, markets, firms, sports leagues, churches, private associations, and governments at all scales. Institutions are essentially contained in a shared language to specify the action that are required, prohibited, or permitted, and the sanctions authorized against rule-infractions. They may facilitate or militate against stable relationships that make interdependence possible and productive for most individuals in the political economy (Commons 1968; E. Ostrom 2005, 3, 18).

Since society is a system of human cooperation, people in any society should collectively relate to and deal with their exogenous variables. Exogenous variables are those conditions that affect human livelihoods and which humans have to work upon through appropriate planning and institutional arrangements to better their conditions of existence. However, there are some fundamental imperatives of collective action within development arena. These are collegiality, mutual trust, reciprocity and shared community of understanding. It is the realization of these imperatives through constitutional reforms, effective planning and institutional arrangements that can enable leaders and the people to work together to achieve meaningful progress.

Cooperation requires deliberation. That is why deliberative democracy is considered more appropriate for Africa. The concept of "deliberative democracy", or "discursive democracy", as a paradigm queries and further strengthens the traditional notion of democracy. Whereas the traditional theory of democracy emphasizes the centrality of voting and parliamentary representation in democracy, deliberative democracy theorists are of the opinion that legitimate lawmaking resides basically in the public deliberation of the citizenry that include marginalized, isolated, ignored groups in the decisionmaking process. The citizens in the democracy structure their institutions such that deliberation in the public realm is the deciding factor in their regular public interactions.

The public sphere represents a social dimension and acts as a mediator between state and society, in which the public organizes itself as the bearer of public opinion (Habermas 1978). It is a social space in which the state and other non-(or anti) state actors operate. Western Europe developed a public realm (collective interests) distinct from the private realm (personal interests), but both are held together by the same Christian beliefs. In Africa, however, colonialism led to a unique historical configuration which led to the emergence of a private realm, and two public realms - the primordial and the civic. These two public realms have different cultural values prevailing within the bureaucracy as against the society. It not only results in attitudes of alienation against the state and its officials but also affects the mental state of public offi- 
cials (Mcmillan 1970; Ekeh 1975). To the extent that they find themselves committed to upholding two contradictory sets of values - those of the modern bureaucracy which they have sworn to uphold and those imposed on them by their traditional environment - public officials become "polynormative", and in many cases, this translates into "normlessness", corruption, 'tribalism', nepotism and personal aggrandizement (Riggs 1962, 29-30). In some cases, post-colonial African elites have used these entrenched systems to plunder national resources, while disregarding democratic norms and traditions (DBSA 2006, vi).

The state in Africa, in spite of its monopolizing posture and domineering tendencies, does not exclusively own African public sphere. Rather, it is merely a co-actor in the public domain. On the other hand, the non-state domain or associational life activities which aim at either limiting the power of the state or ensuring autonomous reproduction of socio-economic and political life constitute civil society. The proprietary attitude of the state towards the public sphere is one driven by political, economic and military resources at the disposal of the state which, it confidently believes, puts it at an advantage over other actors in the public realm. This awesome resource base of the state intoxicates it into believing that not only does it have the power to determine those other actors it will allow to co-habit with it in the public sphere, but it can also drive them out of its "property". This attitude in Africa, observes Ekeh (1992), is radically different from what occurs in the West, where the ruling elite do not claim to own the public space but regard themselves as "the tenants of history" that created the public space.

As a matter of fact, civil society organizations in Africa are autonomous groups which share the public realm with the state and which the state cannot wipe out of existence (Ekeh, 1992). The portion of the public sphere which the state controls can be equated with what Ekeh (1975) calls "the civic public" which in his words operates on "amoral codes of behavior". On public space, Wole Soyinka (1994) warns:

Let all Nigerians understand that the public space means space that belongs to all of us and no group has the unilateral authority to impose and attempt to enforce its own (dress) codes on the rest of us (Soyinka 1994, 33).

The involvement and active participation of citizens in the public sphere for democratic process and consolidation is highly imperative. For example, one of the proud inheritances of South Africa's democracy is public dialogue in the form of community forums, negotiations, and imbizos. ${ }^{2}$ Community forums

${ }^{2}$ Imbizo is a word from the Zulu language in South Africa. It means a "gathering" for the 
have been part of social movements in the fight against both apartheid and posts-apartheid inequalities. Negotiations proudly characterised the transition to democracy which is based on principles of nondiscrimination (Hartslief 2005, 1).

Shortly after independence, in spite of the tremendous contribution of these community-based institutions as exemplified by their remarkable success at building basic infrastructure and services that were financed from locally generated revenue sources (Hicks 1961, Wunsch 2008), the post-colonial African political elites conceived the state as the prime mover of development and this placed the state as the main provider of goods and services required by the people in all spheres of development (Edigheji 2004, 92). Unfortunately, the African state is unable to articulate a transforming project or mobilize society around such a project, as it is not equipped to respond to the needs of the people. In spite of the failure of the African state in governance of the affairs of its people, African people have resorted to trusted institutional arrangement by building confidence and trust in one another, thus collectively decide to create a new organizational structure for the common good (Olowu and Wunsch 2004).

Sheldon Gellar's work (2005) on Democracy in Senegal: Tocquevillian Analytics in Africa provides us vivid examples of associational life in colonial Senegal (1885-1945), civil associations in the postwar era (1945-1960), community-based urban associations, associational life in the countryside, resilience and adaptation of indigenous associations, democracy from below grassroots community-based associations, etc., (Gellar 2005, 94, 107). These groups, since 1996 have come together to establish their own local development committees that engage in a wide range of economic activities, to evaluate their neighbourhood's needs and to develop plans to improve the level of public goods and services (Gellar 2005, 105). These developments in Senegal are slowly changing the nature of local politics by undermining patron-client relationships and party control of associational life and making local government officials increasingly accountable to their constituents rather than to their party (Gellar 2005, 106). However, this remarkably successful institution received relatively little attention from government decision makers and donors, largely because they were not part of national programmes and donor projects (Gellar 2005, 98).

\footnotetext{
purpose of discussing important matters within a group or community. Its ultimate purpose is to ensure participation of members in the process of conceptualising, making and executing decisions. "The imbizo, in its traditional form, has constituted an important aspect of the indigenous African political system for many centuries, especially in Southern Africa (Hartslief, 2005:1).
} 
Government's apathy notwithstanding, there is evidence that civil society i.e. occupational, community-based, and religious organizations - exists at localities all over Africa, and in some circumstances can be an important participant in service delivery and in enforcing accountability (Adedeji, 1997; Coulibally, 1999; Akinola, 2000, 2003a, 2004, 2005d). This self-governing arrangement empowers citizens, protects individual choice and allows for polycentric institutional arrangement that permits citizens to join with one another to take collective action (Wunsch and Olowu 1995, 274). These patterns of self-organising and self-governing capabilities of the local people in resolving their daily challenges are described as polycentricity.

According to Vincent and Elinor Ostrom (2003, 12), polycentricity simply means a system where citizens are able to organize, not just one, but multiple governing authorities, as well as private arrangements, on different scales. Polycentric planning and decision making system enhance the capacity of citizens to talk, discuss, dialogue and engage in contestation in an assembly, whether at local or national level. It deals with multiple units of governments (multi-layers and multi-centers) and a way of working with one another among citizens with complementary arrangements for formulating, using, monitoring, judging, and enforcing rules (Elinor Ostrom 2005).

Though there is a growing awareness of the need to strengthen community institutions which have existed and have facilitated self-reliant development at the local level, these institutions in oil communities of Nigeria exist at grassroots without official connection with the state-based institutions. They operate on a parallel line with governments, their agencies (oil commissions) and oil companies. Under normal circumstances, these people-oriented institutions, governments, NDDC and oil companies should operate in synergy as stakeholders in development and colleagues with equal standing within socio-economic and political arenas in oil communities. This, however, has not been the case. What has been happening is that governments and oil companies dominated decision making arena and decided for the people who have a well established structure of community self-governance (see Akinola $2008 \mathrm{~b}, 92$ ). This is likely to have accounted for unresolved crisis in oil producing communities.

\section{Methodology}

Oil communities in Nigeria comprise nine states and they are Abia, Akwa Ibom, Bayelsa, Cross River, Delta, Edo, Imo, Ondo, and River States. Six of these states formed the area referred to as the Niger Delta while three states (Abia, Imo and Ondo) do not belong to the Niger Delta region but they are called oil producing states. The states within Niger Delta area are Akwa Ibom, 
Bayelsa, Cross River, Delta, Edo, and River States but with several minority tribes such as the Ijaws (mostly found in the riverine area), the Ilaje, the Ogoni, the Itsekiri, the Urhobo, etc. In this paper, for the purpose of uniformity, all the nine states will be referred to as oil producing states while the communities where oil is extracted will be referred to as oil communities. However, the Niger Delta is used as a common currency for all these areas. Data generated and analysed by the author elsewhere (Akinola 2008b) was extracted for the purpose of establishing the foundation upon which restructuring in the Niger Delta could be built. The data were derived from seven Local Government Areas (LGAs) from three of nine oil producing states. They were Gokana, Tai and Khana LGAs, Rivers State; Yenegoa, Sagbama and Brass LGAs in Bayelsa State and Ilaje LGA in Ondo State. The next section of this paper discusses the performance of community self-governing institutions under which the local people operate in the Niger Delta.

\section{The Resilience of Community Self-Governing Institutions in the Niger Delta}

This section was extracted from a recently published article by the author (Akinola 2008b). The section presents alternative self-governance arrangements adopted by the people, having met disappointment from those who run Nigerian government. The people invest their sovereignty horizontally in one another through collective action cum self-organizing and self-governing capabilities and thereby, to an extent, addressing daily challenges - education, health, community hall, postal service, security services, road repairs and other essential services. The discussions cover three major areas - the democratic conditions underpinning self-governance; resources mobilization and public accountability and the contributions of Community Development Associations (CDAs) vis-à-vis that of the local governments in oil communities of Nigeria.

Akinola (2008b:96) identifies two examples of self-governing communitybased institutions in the Niger Delta. They are community development associations (CDA) or town development unions (TDU) and age grade societies. These institutions are charged with the task of mobilizing people and their material resources for community projects. While some social groups have violent orientation, community development associations and age grades function as non-partisan umbrella for rallying community members together in addressing community problems. Membership is a symbol of identity and belonging. The age grade is organized along gender and age lines, while CDA 
is gender and age neutral. Their functions include: (a) infrastructural development of the village or community; (b) settlement of individual and inter-village disputes; (c) promotion of community relations; (d) maintenance of socio-cultural functions; and (e) overall local governance of the community, including the formulation and execution of policies and laws.

While some of these institutions have written constitutions, others depend on oral method. It is, however, instructive to note that oral constitution is very common among these institutions and as a matter of fact, very useful because it is usually 'designed' and amended through community assembly that received adequate participation of members that are endowed with sharp memory. All the people participate in the conduct of their own affairs through free discussion, and act as the final arbiters in the government processes directed by the elders. CDA or town union is an umbrella organization for all the various associations in the Niger Delta. It then becomes easier for decisions taken at the community level to be passed down to all members of the community through the age grades and other associations that constitute communication channels.

The organizational structure and management of these self-governing institutions in the region is unique. The configuration of relationships that bind the people together in these institutions is cultural value (Akinola 2008b, 97). Cultural values of the people play an important role in the operational performance of the institutions. In spite of the socio-economic deprivation the people of Niger Delta were subjected to, the local people still demonstrated commitment to the development of their community. What could have accounted for this? The reason may not be unconnected with their culture. Their contact with the Western culture, notwithstanding, the local people still rely on pre-colonial traditions and experiences of social organization and cooperation. An important aspect of the people's culture is the system of trust and reciprocity that enable them to sustain cooperation. People with a good track record easily secure the confidence of their people in daily interactions. This has tremendously helped these community institutions to build and sustain trusted institutional arrangements. Consequently, these arrangements serve as incentives for leadership in these institutions in rallying their members around community decisions and projects, so as to combat the challenges of daily life where government efforts had faltered.

A familiar code of social justice is applied, and a prudent management of public matters and financial accounts occurs when one considers the impact of resources that were mobilized (as is shown later in this paper). The moral pressure surrounding the public expectation of prudently spending public resources is a living source of public accountability. Embezzlement is very rare 
because of the social stigma it attracts. When this occurs, however, the culprit is made to refund the money and is also fined, suspended, or has his property confiscated and sold to recover the funds. The CDAs/TDUs, however, did not accomplish their goals and objectives without employing certain degree of sanctions on defaulting members. The sanctions, however, vary from community to community.

Akinola (2008b) shows that self-governing institutions, over the years, have initiated and provided public goods and services worth over $¥ 83$ million, an amount that constituted 77.4 percent of 107.3 million, the total cost of the projects. The Local Governments (LGs) in the selected communities contributed $\mathrm{N} 24.2$ million that accounts for 22.6 percent of the total money spent on the same projects. For example, the social impact of the pipe-borne water projects in Nonwa Tai community in Tai Local Government, Rivers State is immeasurable, as the frequent death caused by pollution of stream water from the activities of the oil companies is drastically reduced through the efforts of these institutions. Similarly, the health care project in the same Local Government serves the purposes of child delivery and primary health care service. The Bunu Tai community in Tai LG constructed a bridge to connect the community with farm settlements and fishing ports. Five community development associations in the community contributed $11,243,874.00$ which accounted for $91.8 \%$ of the total cost of the project, while the percentage contribution by the local government was considerably low (8.2\%). Consequently, the ease of accessibility has greatly increased the rate of production, thus enhancing the standard of living in the community. This type of accomplishment is very rare among the officials, whether government or oil multinational companies in the Niger Delta (Akinola 2008b, 99).

The activities of community-based institutions in Bayelsa State confirm the pattern in Rivers State. Five associations in five LGs, like their counterparts in other Niger Delta states focused on water supply, bridge, water transport, education and health. The summary shows that the contributions of these institutions in Bayelsa State accounted for 82.2\%, while that of the LGs was $17.8 \%$, confirming that grassroots represent the prime mover of socio-economic development at the community level. The same pattern exists in Ilaje LGA of Ondo State, where community institutions contributed $70 \%$ towards community development, while the figure for the LG was 30\% (see for details, Akinola 2008b, 101).

The discussions so far confirm that self-organizing and self-governing institutions have impacted positively on the development of grassroots in oil region. Unfortunately, the sampled local governments that received an average of $\$ 30.7$ million per month from the Federal Government in 2002 and 
\$83.8 million per month in 2005 (Tell, No. 42, 17 October, 2005, pp. 2944) performed below expectations in terms of service provision for the people. This appalling performance confirmed what several observers and analysts have identified as the major source of the rising waves of militancy and insecurity in the region.

From the above analyses, it is clear that mass mobilization strategy provides answers to most local development questions which the state has been dodging over the years. Rather than waiting for the local government authorities that are closest to them (and with a lot of money), the local people in oil producing communities, through self-organizing and self-governing capabilities, have planned and executed several social services that directly touch the lives of their people. It is only at this level of common pool resources that some achievements have been realized. This is the doctrine of polycentricity which provides alternative strategies to address problems of daily existence at the grassroots level in the face of dismal and appalling performance of the modern state institutions.

The existence and operation of these self-governing and community-based institutions, however, does not replace the role of government; rather it redefines it. The most important role of government, in a polycentric order, is to help local people resolve their conflicts of interest in a way that remains consistent with societal standards of fairness. In other words, government should not be involved in too many things; rather it should play the roles of facilitator and supervisor to ensure fairness and justice. If these institutions are viable (though not perfect), the question then is: how do we connect them to the formal government structure? The major concern of this paper, therefore, is to design a multi-layered and multi-centered institutional arrangement to ensure community self-governance in the Niger Delta. If this is achieved, the emergence of community self-governing institutions in the Niger Delta can be regarded as the new effort in creating an alternative model of the Niger Delta region built from the grassroots.

\section{Restructuring the Public Sphere Through Polycentric Planning in the Niger Delta}

\section{The Challenge on African Scholars}

This section sheds some light on the role of African scholars on how they can demonstrate their intellectual capability in resolving the crisis in the Niger Delta. Ideally, political leaders and scholars should work together when there 
is a problem to resolve rather than apportion blame when things go wrong. In my own view, there are two options. While in some instances both scholars and governments should work together, in other cases scholars should also be concerned with how to take theories to the streets to proof and test their knowledge. It is not enough to critique the governmental system without offering an alternative workable strategy of how to solve the problems at hand. As the late Michael Manley said:

Those who have to face the challenge of action may make mistakes. Meantime, those who reside permanently in the world of ideas, alone and untested, do not help anyone when they refuse that reality is more complex than theory (Michael Manley cited in Kari Levitt 2005, 302).

In essence, African leaders and scholars, as well as governments and universities, should find a mix of their operations so that their threats can be converted to opportunities. However, since it seems that African governments are not interested in harnessing African knowledge, potentials and skills towards socioeconomic and political development of the continent, it is the contention of this paper that African scholars should be prepared to go the extra mile by fashioning out the possible way forward for the Niger Delta. The critical questions are: Do African scholars continue to generate knowledge for knowledge generation sake and fold their hands on application of knowledge? For how long are they going to maintain this intellectual aloofness? This paper calls the attention of African scholars to this urgent assignment of making their scholarship problem-solving, solution-seeking and relevant to their community.

On the Niger Delta, scholars should use their intellectual capacity to critically study indigenous and endogenous impulses that diverse peoples of Niger Delta are exploiting in surmounting their daily challenges (see Akinola 2007f, 227). This means that Nigerian scholars and other scholars in Africa need to rethink their analytical tools, jettison failed models of development, and discreetly focus on those that can yield enduring socio-economic and political liberation for the Deltans. The fundamental questions include the following: How are the people surviving regarding basic needs like food, housing, clothing, health, education, transport, security, etc.? What lessons can be learnt from the peoples' creativities and the adaptive strategies they evolved over the years in addressing problems of daily existence? These are some of the questions that scholars need to answer through empirical surveys in their various disciplines. Findings from such studies will help come to terms with the resilience and robustness of local people in the Niger Delta as well as their vulnerability, exclusion and marginalization. At the same time, such findings would 
provide guides to African institutions of higher learning and research centers to develop curriculum on both the indigenous and endogenous knowledge systems, thus making African educational system relevant to their communities. In this direction, four tasks need to be performed: (i) Coming to terms with the fact that citizens are sovereign; (ii) Paying close attention to the selforganizing and self-governing structures the people have built and sustained over the years; (iii) Identifying what needs to work upon or filter in order to ascertain what to modify, adopt or reject; (iv) Designing institutional mechanism that can bridge the gap between the ruling elite and the local people; and (v) Designing an interface mechanism that will bring these self-governing structures in line with modern governance.

Since the emphasis of this paper is on how to restructure the public sphere in the Niger Delta, it is apposite at this juncture to demonstrate attempts made by the author, having performed the four tasks, to an extent, at designing an African Public Sphere Restructuring Model (APSRM) that could help in restructuring the public sphere in the region.

\section{African Public Sphere Restructuring Model}

The contention of this paper is that, since political factor determines the operation of other sectors of economy, the starting point is to commence with the application of strategies that can restructure the public sphere in the Niger Delta so that socio-economic and technological crisis in the region can be addressed on pilot scales. The pertinent question at this juncture is: How can we reconstruct and reconfigure the public sphere in the Niger Delta to synergize the efforts of the people through their institutions and that of governments to resolve the lingering socio-economic crises and poverty in the region? How can citizens at community level be mainstreamed in decision making, rule-monitoring and enforcement of sanction on rule infraction? What role should citizens at community level play in policy making?

The African Public Sphere Restructuring Model is conceptualised as a deliberate act of setting up self-governing community assembly (SGCA) for deliberation, collegiality, mutual trust, reciprocity and shared community of understanding. APSRM emphasises two elements - deliberation and deliberateness/action. It derives inspirations and working mechanisms from twelve (12) African development models (Akinola 2007f,g,j; 2008f,m,p). The twelve (12) models are: (1) African Intellectual Gap Measurement Model (AGIMM) for measuring intellectual potentials and relevance of African universities as well as intellectual gap(s) among African scholars with the aim of reforming African educational curriculum and making African scholarship problemsolving and solution seeking (see Akinola 2008m for details on this model); 
(2) African Development Institutional Mechanism (ADIM) for connecting all the stakeholders in development at various levels of decision making (Akinola 2007f); (3) African Polycentric Information Networking (APIN) for creating networks between the leaders and the people for effective information sharing and communication (Akinola 2008p, 188-189); (4) African Food Security Model (AFSM) for securing food for the citizens (Akinola 2008f,p, 193-195); (5) African Employment Generation Model (AGEM) for generating employment opportunities (Akinola 2008p, 193-195); (6) African Conflict Prevention and Peace Building (ACPPB) for detecting and preventing conflict as well as building peace (Akinola 2008p, 189); (7) African Sustainable Environment Model (ASEM) for conserving and protecting environmental resources (Akinola 2008q); (8) African Road Triology (ART) for building cost effective and durable roads (Akinola 1998); (9) African Community-Initiatives and Development Model (ACID) for empowering the people economically and reducing poverty (Akinola (2000, 186-187); (10) African Electoral Reform and Democratisation (AERD) for inclusive democratisation (Akinola 2008p, 192-193); (11) African Local Economic Development Strategy (ALEDS) for enhancing economic growth through local industrialization and sustaining development (2007f, 233; 2008f,p, 190-191); and (12) African Polycentric Privatisation Model (APPM) for distributing the benefits of economic growth among the citizenry (Akinola 2007f, 233).

The African Public Sphere Restructuring Model (APSRM) is diagrammatized in Fig. 1. The first part of the diagram displays the failure of structurallydefective public landscape and public policies in Africa as exemplified by parallel operations of the four terrains of public landscape (civil society; economic society; political society and public sphere) that has resulted into elite dominated economy and socio-economic and techno-political crisis, which have, in turn, deepened poverty and heightened human misery in Africa. This failure calls for a paradigm shift in governance structure to a new institutional arrangement whereby the efforts of the participants in the public terrains politicians, bureaucrats, technocrats, scholars, multinationals and citizens - are synergized through public sphere restructuring mechanism. The restructuring process will commence, first, with the setting up of self-governing community assembly (SGCA) where participants through their institutions (governments with their agencies, higher institutions, community institutions) can operate in synergy. The second step is a value re-orientation among African scholars, public officials and other participants. This new orientation, invariably, determines: (a) the ability of African scholars to take theories to the streets and applied them for the benefit of the citizenry; (b) the synergy between and among African scholars and public officials in executing socio-economic 
and techno-political projects; (c) the relevance and indispensability of community self-governing institutions in decision making; and (d) the centrality and imperativeness of community assembly for the resolution of crisis.

Third, the participants would operate using rules that are crafted by members at the SGCA. Rule crafting takes place at three levels - constitutional, collective choice and operational. At the constitutional level lies the system that determines how rules are made and can be modified. At the heart of effective governance of Niger Delta is the imperativeness of constitutional reform which can be accomplished through pragmatic experience, for example, polycentric privatization and local industrialization. The effectiveness of this strategy has been proven in an experiment performed in Irepodun Local Government area of Osun State, Nigeria between 2005 and 2006 by the author (Akinola 2007f, 230). Based on the Irepodun experience, adopting polycentric privatization strategy could avail the citizens in the Niger Delta the opportunities to dialogue in community assembly and jointly take decision on how resources are to be allocated and utilized. At the collective choice level, rules that define and constrain the actions of individuals and citizens have to be established. At the operational level, concrete actions have to be undertaken by those individuals most directly affected, or by public officials (McGinnis 1999a).

Fourth, the outcome of the restructuring is emergence of new institutional arrangements, which would reflect integrative constitutional order in socioeconomic and techno-political realms. It is this joint action and synergy by the three groups (scholars, public officials and representatives of community selfgoverning institutions) that would eventually determine how government policies in all spheres of life are to be implemented. After the institutional arrangement has been designed, an operational strategy for implementation of any programme/project (e.g. employment generation, food security, road development, poverty reduction, environmental management, electoral reform and democratisation, conflict detection, prevention and resolution, etc.) can then be fashioned out (see Akinola 2007f; 2008b,p). It is at this stage that any of the twelve models can be applied to any of the specific action situations. The result of restructuring as shown in Fig. 1 is sustainable development.

\section{Prognosis and Lessons for Africa}

The Niger Delta people across all ages, in self-governing institutions practice self-rule (democracy) by participating in meetings, voting for officials, making those officials accountable to the other members of the group, deliberating about common concerns, paying their dues in a timely manner, and serving 


\section{Figure 1}

African Public Sphere Restructuring Model (APSRM)

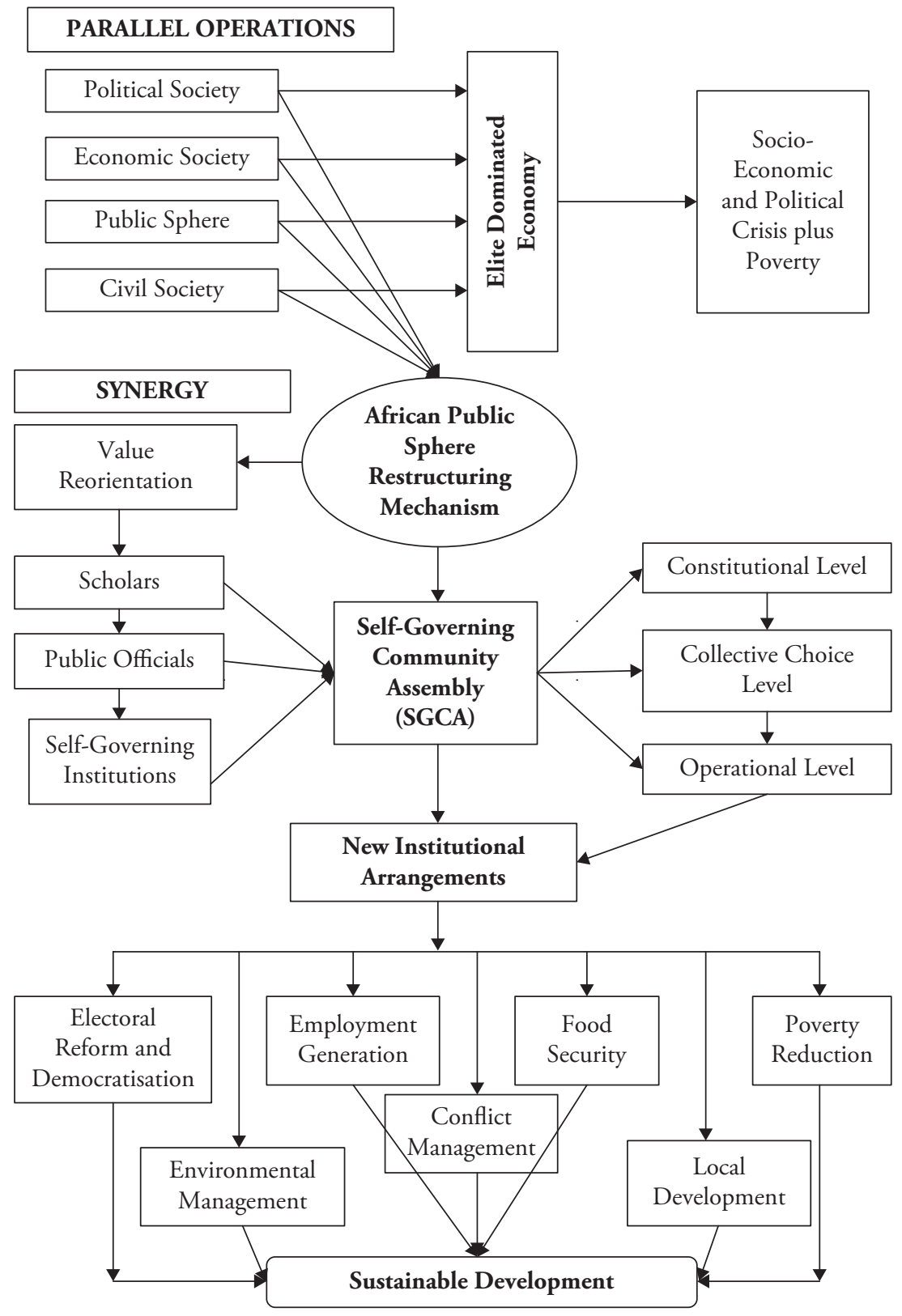


on juries that were responsible for enforcing the norms and statutes of the group. The significant aspect of these institutions is that they never went into extinction; rather, they are resilient and constitute the tools of survival among the local people in the region. The lesson we can learn from these institutions is how they are able to mobilize and use resources judiciously for the provision of social services.

In light of the above, it is clear that the social disparity between the Nigerian state, its oil partners, and the oil communities could be addressed if the public sphere is restructured using polycentric planning mechanisms to produce new institutional arrangements capable of bringing all the stakeholders together for regular discussions, deliberation and decision making. Such public sphere restructuring should regard the existing self-organizing and selfgoverning arrangements that have proved effective, as building blocks for re-constituting order from the bottom up in oil region. A community assembly that comprises officials of governments and oil companies as well as representatives of various groups and associations (including the warring factions) in the Niger Delta should be established. The self-governing institutions can act as checks and balances on the local government officials.

Other African countries with oil resources have some lessons to learn from the Niger Delta experience. Besides, countries that are passing through conflicts could adopt polycentric planning and self-governing arrangements in their decision making systems to ensure inclusive resource utilization. In polycentric and self-governing systems, citizens, interacting through appropriate institutional arrangements, engage in rule making at all levels of decisionmaking (operational, collective choice, and constitutional) and within all scales or domains (neighborhood, township, local government and state). Boundaries between the three decision making levels are blurred. Depending on the activity at hand, two or all the three actions can take place within a particular scale or domain.

It is believed that when the participants and stakeholders at the community assembly are able to sit together, discuss their common problems and craft working rules together, a shared community of understanding would be established. The interactions between the governments, oil companies and self-governing institutions would eventually produce new working relations that will be people-oriented. For governance to benefit the people it has to proceed from the people, be guided by them, and they should be able to modify the governing institutions as their situations change. The argument is that if Nigeria or any African country wants to address the problem of marginalization, exclusion, infrastructural deprivation, corruption and poverty in the oil communities, it needs to learn how to make efficient use of her physical, human, 
and institutional resources. Experiences of community-based institutions in such communities through self-organizing and self-governing capabilities in meeting common challenges in the delivery of common goods and social services need to be taken into consideration in policy formulation. It is these people-designed and people-oriented structures that can be regarded as building blocks for the emergence of a people-centred and self-governing public sphere capable of reconstituting order from the bottom-up in the Niger Delta and Africa. The African Public Sphere Restructuring Model could be implemented on pilot scale before it is replicated. Lessons that are learnt from pilot projects would be used in refining the model for full replication across the Niger Delta region and Africa.

This paper concludes that the failure of structurally-defective governance in the Niger Delta calls attention to polycentric planning and decision making arrangements whereby community self-governing institutions could play critical and indispensable role by bringing the Niger Delta people into the main stream of socio-economic and techno-political decisions, thus synergizing the efforts of the state, oil companies and community institutions through bottom-up and integrative planning. It is strongly believed that community selfgoverning institutions are capable of valorising the restructuring process of the public sphere for mutually productive ways of life. In view of the resilience and robustness of community self-governing institutions in meeting the aspirations and yearnings of the citizens in the Niger Delta, any attempt to neglect them in the process of restructuring the public sphere would constitute a missed opportunity for the Niger Delta or any other African country with similar experience.

\section{References}

Adedeji, Adebayo. 1997. "Popular Participation, Democracy and Development: Is there a Dialetical Linkage?” In Nigeria: Renewal from the Roots, ed. Adebayo Adedeji and Otite Onigu, 3-19. London and New York: Zed Books.

Akinola, Shittu R. 1992. Governance and the Deprived Group: A Case from Oil Producing Region of Nigeria. Journal of Nigerian Public Administration and Management 2(2):68-77.

— 1998. "Oil Prospecting, National Integration (Unity) and Sustainable Development in Nigeria." In Book of Readings on Education, Environment and Sustainable National Development, ed. Obidi, S.S., E.R.I. Afolabi, M.A. Adedibu and S.V. Kobiowu, 285-296. Ibadan: Cardinal Crest Limited.

— 2000. "Balancing the Equation of Governance at the Grassroots." In People-Centred Democracy in Nigeria? The Search for Alternative Systems of Governance at the Grassroots, ed. Adebayo Adedeji and Bamildele Ayo, 171-197. Ibadan: Heinemann.

- 2003a. Resolving the Niger-Delta Crises through Polycentric Governance in Nigeria. Paper presented at a Colloquium organized by the Workshop in Political Theory and Policy Analysis, 1 December, in Indiana University, Bloomington, USA. 
2004. Local Self-Governance as an Alternative to Predatory Local Governments in Nige-

ria. International Journal of Studies in Humanities 1(3):47-60.

2005d. "Structural Transformation and Polycentric Governance: Complementary Strategy towards Nigeria's Reform Agenda”. Proceedings of the 14th General Assembly of Social Science Academy of Nigeria, 238-250 in Abuja, Nigeria.

2007a. Coping with Infrastructural Deprivation through Collective Action among Rural People in Nigeria. Nordic Journal of African Studies 16(1):30-46.

_ 2007f. Knowledge Generation, Political Actions and African Development: A Polycentric Approach. International Journal of African Renaissance Studies 2(2):217-238.

- 2007j. "Africa’s Liberation Project and Redemptive Development." A Proposal Submitted to The Chancellor, Bishop (Dr.) David Oyedepo, Covenant University, for the setting up of African Development Centre (ADC) at the Covenant University, 10 Idiroko Road, Canaan Land, Ota, Ogun State, Nigeria, November 30.

— 2008b. Coping With Social Deprivation through Self-Governing Institutions in Oil Communities of Nigeria. Africa Today 55(1):89-107.

— 2008f. "The Role of Covenant University in Ensuring Food Security and Employment Generation in Africa: The Polycentric Planning and Poverty Reduction Strategy (PPPRS)." A Proposal Submitted to The Chancellor, Bishop (Dr.) David Oyedepo, Covenant University, Covenant University, 10 Idiroko Road, Canaan Land, Ota, Ogun State, Nigeria, June 26.

_ 2008m. "African Scholars and the Challenge of Development: Toward a Problem-Solving Regime in Africa" Paper sent to The Journal of Pan African Studies.

_ 2008p. "Alternative Planning Models for Development in Africa." In Knowledge to Remobilise Africa. ed. The Development Bank of South Africa, 169-202. Johannesburg: Knowledge Management Division.

_ 2008q. "Reducing Environmental Degradation and Poverty through Environmental Governance in Nigeria." In Environmental Impact Assessment Studies and Planning Perspectives, ed. S. Padmaja, N.C. Gautam and M.A. Ali, 41-74. SultanBazar, Hyderabad: BS Publications.

Alger, Dean. 1998. Megamedia: How Giant Corporations Dominate Mass Media, Distort Competition and Endanger Democracy. Lanham, Md.: University Press of America.

Ayittez, G.B.N. 1991. Indigenous African Institutions. New York: Transnational Publishers.

2006. Africa Unchained: The Blueprint for Africa's Future. Palgrave Macmillan, USA, ISBN: 978-1-4039-7386-3; ISBN-10: 1-4039-7386-5. http://www.shvoong.com/books/1783537africa-unchained-blueprint-africa-future/ (accessed May 5, 2009).

Ayo, S.B. 2002. Public Administration and the Conduct of Community Affairs Among the Yoruba in Nigeria. Oakland, California: Institute for Contemporary Studies.

Berger, Peter L. 1986. The Capitalist Revolution: Fifty Propositions about Prosperity, Equality and Liberty. New York: Basic Books.

Bibic, Adolf, and Gigi Graziano. 1994. Civil Society, Political Society and Democracy. Ljubljana: Slovenina Political Science Association.

Colas, Dominique. 1997. Civil Society and Fanaticism: Conjoined Histories. Stanford, Calif.: Stanford University Press.

Commons, John R. 1968. Legal Foundations of Capitalism. Madison: University of Wisconsin Press, First Published in 1924.

Coulibally, C. 1999. "On subsidiary in West Africa: A Contribution to Institutional Problem Solving in Africa." Paper presented at the Workshop 2 Conference, Workshop in Political Theory and Policy Analysis, Indiana University, Bloomington, Indiana.

DBSA 2006. Knowledge to Address Africa Development Challenges. Johannesburg: The Development Bank of South Africa (DBSA), Knowledge Management Division.

Diamond, Larry. 1999. Developing Democracy: Toward Consolidation. Baltimore, Md.: Johns Hopkins University Press. 
Douglas, O., and D. Ola. 1999. "Defending Nature, Protecting Human Dignity - Conflicts in the Nigeria Delta." In Searching for Peace in Africa: An Overview of Conflict Prevention and Management in Africa. ed. Mekenkamp, M., P. Van Tongeren, and H. Van de Veen. Utrecht: European Platform for Conflict Prevention and Transformation, in Cooperation with the African Centre for the Constructive Resolution of Disputes.

Edigheji, O. 2004. The African State and Socio-Economic Development: An Institutional Perspective. African Journal of Political Science 9(1):84-104.

Ekeh, Peter. 1975. Colonialism and the Two Publics in Africa: A Theoretical Statement. Comparative Studies in Society and History 17(1):91-112.

1992. "The Constitution of Civil Society in African History and Politics." In Democratic Transition in Africa, ed. Caron, B., A. Gboyega, and E. Osaghae, 187-212. Ibadan: CREDU.

FGN (Federal Government of Nigeria). 2008. Sustainable Development in the Niger Delta - The Master Plan Road Map 2020 (1960-2007). A Consolidation of Democracy.

Forment, C. A. 2003. Democracy in Latin America (1760-1900), Vol. I. Chicago and London: The University of Chicago Press.

Gellar, Sheldon. 2005. "The Art of Association." Democracy in Senegal: Tocquevillian Analytics in Africa. New York and Basingstoke: Palgrave Macmillan.

Habermas, Jurgen. 1978. "Legitimation Problems in the Modern State." In A History of Sociological Analysis. ed. Habermas, Jurgen, 3-38. London: Heinemann.

1989. The Structural Transformation of the Public Sphere. Cambridge, Mass.: MIT Press.

Hamilton, Alexander, John Jay, and James Madison. 1961. The Federalist. ed. Edward M. Earle. New York: Modern Library, [1788].

Hann, C.M. 1990. Market Economy and Civil Society in Hungary. London: F. Cass.

Harbeson, J.W., D. Rothchild and N. Chazan. 1994. Civil Society and the State in Africa. Boulder, Colo.: L. Rienner Publishers.

Hartslief, O. 2005. The South African Presidential Participation Programme (Presidential Imbizo): Engaging Communities for a Better Life. An unpublished paper, 2005. (http://www.engagingcommunities2005.org/abstracts/S14-hartslief-o.html), Accessed May 25, 2009.

Hicks, U.K. 1961. Development from Below: Local Government Finance in Developing Countries of the Commonwealth. London: Oxford University Press.

Hirst, Paul. 1994. Associative Democracy: New Forms of Economic and Social Governance. Amherst: University of Massachusetts Press.

Huntington, Samuel P. 1968. Political Order in Changing Societies. New Haven, Conn.: Yale University Press.

Janowitz, Morris. 1983. The Reconstruction of Patriotism: Education for Civic Consciousness. Chicago: University of Chicago Press.

Kuttner, Robert. 1997. Everything for Sale: The Virtues and Limits of Market. New York: Alfred A. Knopf.

Levitt, Kari. 2008. Reclaiming Development: Independent Thought and Caribbean Community. http://books.google.com/books?hl=en\&lr=\&id=pAo83TRbyCMC\&oi=fnd\&pg=PA6\&dq= $\% 22$ Levitt\%22+\%22Reclaiming+Development:+Independent+Thought+and+..\%22+\&ots =2BiAhe3kWW\&sig=kr-yDtXoXjahin_SoQ9P5_cpRG8\#PPP1,M1 (Accessed 12/10/2008).

Lomnitz, Claudio. 2001. Deep Mexico, Silent Mexico: An Anthropology of Nationalism. Minneapolis: University of Minnesota Press.

Mansbridge, Jane. 1983. Beyond Adversary Democracy. Chicago: University of Chicago Press.

Macmullan, M. 1970. "Corruption in the Public Services of British Colonies and Ex-colonies of West Africa." In Political Corruption: Reading in Comparative Analysis, ed. Heidenheimer, A. J., 317-330. New York: Holt, Reinhart and Winston.

McGinnis, M.D. 1999a. Polycentric Governance and Development: Readings from the Workshop in Political Theory and Policy Analysis. Ann Arbor: The University of Michigan Press. 
Mitchell, Neil J. 1997. The Conspicuous Corporation: Business, Public Policy and Representative Democracy. Ann Arbor: University of Michigan Press.

Naanen, B. 1995. Oil Producing Communities and the Restructuring of Nigerian Federalism: The Case of the Ogoni People. Journal of Commonwealth and Comparative Polities 33(1): 126-155.

Novak, Michael. 1982. The Spirit of Democratic Capitalism. New York: Simon and Schuster.

Obi, Cyril I. 2000a. Globalized Images of Environmental Security in Africa. Review of African Political Economy 27(83):47-62.

2004. "Globalization in Nigeria’s Oil Industry: Implications for Local Politics." In Nigeria's Struggle for Democracy and Good Governance: A Festschrift for Oyeleye Oyediran. ed. Agbaje, A. A. B., L. Diamond, and E. Onwudiwe, 441-460. Ibadan: University Press.

Okaba, Benjamin O. 2005a. Petroleum Industry and the Paradox of Rural Poverty in the Niger Delta. Benin City, Nigeria: Ethiope Publishing Corporation.

_ 2008. "Petrodollar, the Nigerian State and the Crises of Development in the Niger Delta Region: Trends, Challenges and the Way Forward." Unedited conference proceedings, International Conference on 'The Nigerian State, Oil Industry and the Niger Delta,' 21-39. March 11-13, in Yenagoa, Bayelsa State, Nigeria. Port-Harcourt: Harey Publications Company.

Olowu, Dele. 1999. "Local Organizations and Development: The African Experience." In Polycentric Governance and Development: Readings from the Workshop in Political Theory and Policy Analysis, ed. McGinnis, M. D., 209-240. Ann Arbor: The University of Michigan Press.

— 2006. "Towards a Local Governance and Poverty Reduction Programme at the African Development Bank." In Local Governance and Poverty Reduction in Africa, ed. Millett, Karin, Olowu Dele \& Cameroon Robert. 7-28. ADB, IMF \& The World Bank. Published for the Joint Africa Institute.

Olowu, Dele and James Wunsch. 2004. Local Governance in Africa: The Challenges of Democratic Decentralization. Boulder, Colorado: Lynne Rienner Publishers.

Ostrom, Elinor. 2005. Understanding Institutional Diversity. Princeton and Oxford: Princeton University Press.

Ostrom, V. and E. Ostrom. 2003. Rethinking Institutional Analysis: Interviews with Vincent and Elinor Ostrom. Commemorating a Lifetime of Achievement, Mercatus Centre, George Mason University, USA, November 7.

Ostrom, Vincent, Robert Bish, and Elinor Ostrom. 1988. Local Government in the United States. San Francisco, California: Institute for Contemporary Studies Press.

Putnam, Robert. 1993. Making Democracy Work: Civic Traditions in Modern Italy. Princeton, N.J.: Princeton University Press.

Riggs, F.W. 1962. "Convergences in the Study of Comparative Public Administration and Local Government." Public Administration Clearing Services of the University of Florida, Gainsville FL. Series in Public Administration, No. 23.

Sawyer, Amos. 2005. Beyond Plunder: Toward Democratic Governance in Liberia. Boulder, Colorado: Lynne Rienner, Inc.

Schudson, Michael. 1998. The Good Citizen: A History of American Civic Life. New York: Martin Kessler Books.

Soyinka, Wole. 1994. Democracy and the University Idea: The Student Factor. The Guardian, May 27, p. 33.

Tocqueville, Alex. 1966. Democracy in America, Vols. 1\&2, Phillips Bradley, (Ed), New York: Vintage Books, (First Published in 1835 and 1940).

Walzer, Michael. 1995. "The Concept of Civil Society." Toward a Global Civil Society, 7-28. Providence, R.I.: Berghahn Books.

Watts, Michael. 2008. "The Rule of Oil: Petro-Politics and the Anatomy of an Insurgency." Unedited conference proceedings, International Conference on 'The Nigerian State, Oil 
Industry and the Niger Delta,' 40-52. March 11-13, in Yenagoa, Bayelsa State, Nigeria. PortHarcourt: Harey Publications Company.

Wunsch, James S. 2008. "In the Shadow of "Lame Leviathans": Collective Action and Local Governance in Africa." Paper presented at a colloquium organized by the Workshop in Political Theory and Policy Analysis, March 3. at Indiana University, Bloomington, Indiana, USA.

Wunsch, James S. and Dele Olowu. 1995. The Failure of the Centralised State: Institutions and Self-Governance in Africa. Boulder, Colorado: Westview Press.

Wuthnow, Robert. 1998. Loose Connections: Joining Together in America's Fragmented Communities. Cambridge: Harvard University Press. 